WORK SESSION

Wednesday, November 16, 1988

\title{
Intermodal Freight Transportation
}

\author{
Moderator \\ Dick Cirre \\ Executive Director \\ Kentucky Port \& River Development Commission
}

\section{Panelists}

Larry Prather

Assistant Chief, Planning

U.S. Army Corps of Engineers

Anthony V. Reck

President

Paducah \& Louisville Railway, Inc.

Charles F. Lehman

Vice President

American Commercial Barge Lines 


\section{Intermodal Freight Transportation}

\section{INTRODUCTIONS}

Moderator, Dick Cirre, is Executive Director of the Kentucky Port and River Development Commission and is responsible for the administration of all riverport and waterway transportation matters for the Commonwealth. Mr. Cirre earned his BS in Civil Engineering from Princeton University and his MS in Regional Planning from Cornell University.

Larry Prather, an economist, serves as Assistant Chief for Planning with the U.S. Army Corps of Engineers and is stationed in Cincinnati.

Anthony V. Reck, President of Paducah \& Louisville Railway, is a native of Illinois where he earned a BS in Business Administration from Southern Illinois University. He earned his MA in Business Management from Webster College in St. Louis. Mr. Reck joined the Paducah \& Louisville Railway in 1986 as director of marketing and a year later was elected vicepresident of marketing, before being elected to serve as president.

Charlie Lehman has served as Vice

President of Public Affairs for the American

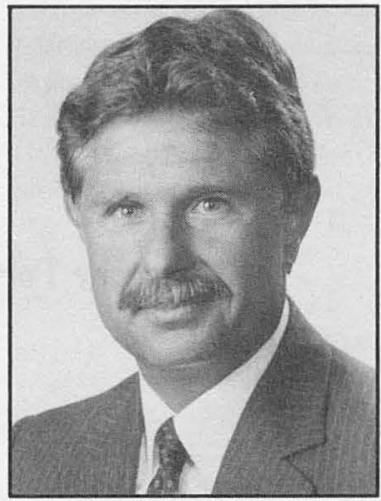

Tony Reck Commercial Barge Line Company since 1978.

Due to Mr. Lehman's interest in the safe navigation of vessels on our nation's waters, he has served on various advisory committees of the U.S. Coast Guard and other federal committees and is active with inland waterway industry associations.

\section{The Future of Intermodal Freight Transportation}

\section{by Charlie Lehman}

Intermodal transportation involves two or more different methods of taking freight from an initial origin to a final destination. When attempting to assess where we are and where we would like to be intermodally in the future, one must first remember that the entire transportation service business is extremely capital intensive, and secondly, the future is usually measured in large blocks of time.

As regards capital requirements for our inland river industry, lock and dam structures are usually considered to have a 50-year economic life. Towboats are operating today that were built over 50 years ago. The Corps of Engineers is forecasting, for planning purposes, waterway infrastructure needs to at least the year 2040. The American Association of State Highway Transportation Officials has developed its year 2020 "Beyond Gridlock" program for what it believes will be our country's 
transportation requirements. In the context of future planning for our government, the Congress, however, looks at a two-year cycle for transportation authorizations and only one year for appropriations. Sometimes they can't even make that.

Once in a while I pick up the "Futurist" magazine which tries to foresee not only the coming half-century's business and life-style trends, but beyond that into the following age of 3001. Its visions of the future are interesting, fascinating, and even possible, but are beyond every CEO's ability to convince a board of directors to make major capital financial commitments today to meet those ideas the futurists believe will be tomorrow's age; therefore, we have put into perspective what is meant by the "future".

Where will we be on the waterways in 2038 , fifty years hence? Will we be close to the Corps of Engineer's current long-term planning cycle? Perhaps we ought to reflect on where we were 50 years ago. In 1938, we river folk were just recovering from the record Ohio River flood of 1937 . We were still in the depression period, and World War II was in the making. There were lots of steam stern-wheel towboats plying the rivers and not many of the diesel-powered screw-propeller type. The future was not predicted as to what our river transportation system has become a half-century later.

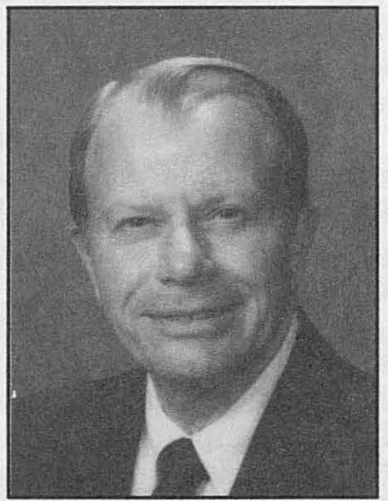

Charlie Lehman

Even 40 years ago, just as we emerged

from World War II, it would have been difficult to see what 1988 would provide. Nineteen forty-eight was the year that saw the blockage of Berlin by the Russians, the State of Israel came into existence, country music star Larry Gatlin of the Gatlin Brothers was born, and modern barging (pretty much as we know it today) was emerging. Optimism about river growth was high.

Thirty years ago, in 1958, Eisenhower was president and Michael Jackson with his high-pitched voice was brought by his obstetrician screaming into the world. American Barge Line and Commercial Transport Corporation had joined together the previous year to form American Commercial Barge Line Company offering full contract and common carriage on the entire mid-continent inland river system. Diesel fuel was less that 10 cents a gallon and the future was looking good.

Since that time we have had our peaks and valleys of economic opportunity and optimism, but to think that we could predict 50 or 40 or even 30 years ago where we would be today is simply hindsight and not much of a guide for an attempt to foretell the future of 2018,2028 , or 2038 -- fifty years from now.

The possibility of a quantum leap in technology increases every day in this computer age and could very likely lead to new ways in which commodities and products move by surface transportation. Can we really predict how these unknown ideas will affect river traffic? First we have to ask, will superconductivity mean that the existing business of fossil-fueled 
steam power plants located in the Ohio and Mississippi basins supplied by coal barges need to produce more kilowatts for the nationwide electrical grid, or will more efficient plants, however costly, be built at mine mouth sites? Will this nation overcome its fears of the Seabrook and Chernobyl disasters and go back to building nuclear power plants? Is it possible we might have a hydrogen economy?

Will genetics make foreign nations self-sufficient in food requiring less grain exports, or will world population growth outpace new technological discoveries? People will always require bodily nourishment. Will synthetic materials displace more and more steel in many products? Will weather patterns change to make a new ice age as was predicted during the back-to-back iced over Ohio River winters about 10 years ago? Or does the drought of the summer of 1988 foretell a future of a much warmer climate affecting crops, transportation, and life-styles?

What will the government do? Will laws be passed to expand or restrain trade? Will legislation and regulations encourage or discourage innovation? Will tax policy, labor concerns, environmental policy, defense priorities, and agricultural programs be promoted, or relegated to a bottom drawer?

We could draw an existing trend line for most of these possibilities as to what we know now and what has been happening. Trend lines, however, tend to plateau or even reverse. The future can be, and should be, contemplated, studied, and even planned for, but predictions for 30-4050 years out are constrained by our myopic view of what is currently known and seemingly practicable. Certainly we have to be able to make intelligent forecasts regarding the previous questions I have posed before we can predict what will occur in the transportation of products either by individual mode or intermodal.

All of this is esoteric in outlook and not too helpful in planning a career or an investment. However, parameters of the possible have to be drawn in order to make intelligent investment decisions. We are here to discuss intermodalism and the outlook for the part our river industry will play. Almost all products moved on the inland waterways of the United States are in fact intermodal in nature. The coal, grain, steel, fertilizer, salt, and scrap metal transported by barge is originally or subsequently moved by another mode of transport. Coal typically moves by truck or rail to a river dumping tipple and then to destination by barge. Trucks or trains move grain to an elevator which transloads to a barge which ultimately moves to another elevator for transfer to an ocean-going ship. Steel may arrive at a dock by truck, load into a barge, unload at a general cargo terminal and then be railed or trucked to its final place of use.

If, however, one ignores these real world examples and defines intermodal to mean a single contract by a shipper with one transporter utilizing different modes in handling the movement, intermodalism has not had a huge impact on our river industry. Cargo moved with one transportation contract has increased at ACBL and currently amounts to about 6 percent of our traffic, mostly coal. I suspect that other inland water carriers move substantially less of their traffic under a single contract than we do. For the most part, shippers who presently use 
different modes to convey their products to their customers deal separately with each individual modal carrier. We, as a partner in the CSX family, hope to change the practice as we believe one-stop shipping many times makes more economic sense for a shipper than trying to coordinate a movement with a variety of carriers and contracts.

The one subject that planners, consultants, and transportation specialists continually ask about is container shipments on the river. Well, it's certainly not a new idea and it may or may not be the wave of the immediate future. Looking back again to 30 years ago (1958) when I was a river pilot, we (ACBL) brought a couple of tow loads of containers from New Orleans to St. Paul, Minn. I thought at that time this was the beginning of a significant new business. I believed we would have a continual trade of containers moving on the entire river system. Apparently, the economics didn't work out, because after those two movements we never saw another container moving on the rivers for many years.

Then in 1982, a shipping agency, Tricon, started offering container-on-barge shipments from New Orleans. Although it looked like it might be a good idea, the movement never caught on, and the company ceased operations four months later. In 1984, Leaseway Transport Corporation started up a container-on-barge operation offering a scheduled weekly service between New Orleans to Memphis, St. Louis, and Chicago. It was quickly restricted to a New Orleans-Memphis trade, but it, too, only lasted about four months.

Many factors are probably attributable to the inability of container barge movements to catch on. Containers are generally time-sensitive. Operational and weather conditions are such on the Mississippi and Ohio River systems that the barged container traffic would have to be with non-time-sensitive containers. Towboats are a lot slower than rail container trains or truck container movements and are subject to delays due to low water, fog, or channel congestion. Demand is a factor. Each barge can carry about 36 FEU's (Forty-foot Equivalency Units). To gather and pool a group of barges for a particular upstream port takes a large customer or a lot of smaller ones. Do you build the specialized inland terminals with ability to quickly handle modern containers and attract shippers, or do you try to line up shippers to use makeshift facilities prior to investing capital for efficient long term operations? Handling costs are not cheap. Start-up will mean low initial volume until the service sells its worth to shippers and commitments can be made.

Generally, non-time-sensitive traffic is of lesser value and consequently transportation rates are low. Competition between rail companies and trucking for this traffic is high and it could be touch and go for a new venture company to obtain a market share unless it had adequate capital to sustain the costs of establishing an initial base.

The Columbia River system on the West Coast has had successful container traffic since 1975. Mainly it is a one-way movement of wood chips for export. Technically, there is no reason why barging of containers cannot be accomplished on the Mississippi River system -- at least while 
there is an open channel not constrained by locks. Technically feasible, yes, but so far the economic question as to whether it can be profitable has proven to be negative.

It would probably take a ratable and sustainable annual level of about 10,000 FEU's to make the start-up investment of two-way container traffic viable. Whether those traffic patterns are in the future for our river system is difficult to answer. As more and more cargo becomes containerized, I would venture to say yes, but I cannot predict which decade would see it successful. I do believe, however, that one-way traffic of loaded northbound containers on barges moving out of the port of New Orleans to the mid and lower Ohio, and perhaps St. Louis, as a backhaul is very possible for one-time-sensitive traffic. The containers would then be reloaded and taken to port cities by truck or rail for export via ocean liner.

Looking ahead into early 2000 , we can visualize many improvements utilizing existing technology, including improved communications, more stable channel conditions, and better electronic devices. There will be advanced nuances of what we know today, but I do not see a clear picture in the crystal ball which would lead to a startling breakthrough dramatically changing the way barge traffic is presently moved.

We in the river industry intend to be around providing low cost bulk movements of the basic building blocks of our agri-industrial economy until at least the 50th Transportation Forum is celebrated, 25 years from now. Invite me back then, and I'll fly here by my Buck Rogers self-propelled backpack, put on a laser 3-dimensional show explaining our new robot controlled towboats with no propellers. Their power will be supplied by hydrogen converted from river water with a jet thrust. Our boats will be pushing self-unloading barges which will be unsinkable. They will be coupled together by electromagnets. Then I'll explain to all present what is in store for you on your 75th anniversary. 